\title{
Correlation study between physical disability and covid-19 cases in Sleman, Indonesia
}

\author{
Ihsan Weda Prabaswara ${ }^{1}$, Agustin Putri Samsiana ${ }^{2}$, Nabilah Luthfatur Rohmah ${ }^{1}$, Nabiyya Perennia $^{1}$, Nasrudin Dwi \\ Jatmiko $^{1}$, Nawang Setyoningsih ${ }^{2}$, Mya Dwi Rostika ${ }^{3}$, and Ratih Fitria Putri ${ }^{*}$ \\ 'Environmental Geography Department, Faculty of Geography, Universitas Gadjah Mada, Yogyakarta, 55281, Indonesia \\ ${ }^{2}$ Development Geography Department, Faculty of Geography, Universitas Gadjah Mada, Yogyakarta, 55281, Indonesia \\ ${ }^{3}$ Department of International Relations, Faculty of International Relations, Daito Bunka University, Japan
}

\begin{abstract}
The spread of the highly infectious COVID-19 has severely impacted the global community. Population density and intense physical interaction are the catalysts of the virus spread. Many regulations were issued to halt the spread of the virus, including the limitation of people's mobility and physical interaction. With the limitation of mobility and physical interaction, many people with disabilities are struggling to access their needs since they depend on their caregivers. The lack of inclusive policies in the health system itself also ends up deprioritizing the disabled. This article aims to identify the correlation between physical disability and COVID-19 cases and identify the spatial distribution of the correlation in Sleman regency, Indonesia. This article presents the correlation with the qualitative approach using Pearson product-moment correlation method. The data used in this article is secondary data obtained from official government agencies. The findings of this study showed that Pearson correlation between physical disability and COVID-19 cases is 0,04346 and classified as very low positive.
\end{abstract}

\section{Introduction}

The waves of COVID-19 pandemic have severely impacted the community throughout the world, including Indonesia. The pandemic is highly infectious and airborne, making it even more widespread [1]. Intense physical interaction between people performs as the catalysts in the spreading of the virus which causes the disease. The virus rapidly spread in high density area [2].

Sleman Regency which is situated in the Special Region of Yogyakarta, has recorded the rise of cases through 2020 between April and December with the highest record of infected people being 109 cases in a day on December 16th, according to COVID-19 Regency Task Force. To counter the spreading of the virus, the local government has authorized the community to restrict their social activities and to obey the health protocols with various regulations, such as Keputusan Bupati Sleman No. 25/Kep.KDH/A/2020, Peraturan Bupati Sleman No. 37.1/2020, and Instruksi Bupati Sleman No. 443/01032/INSTR/2020 and No $5 /$ INSTR/2021. This regulation was meant to halt the spread of the virus by limiting people's mobility and physical interaction; and ensure that the community is protected from the virus. However, the implementation of the regulation has presented its own challenges.

One of the more common analyses is the effect of economic class on COVID-19 vulnerability, as people with higher economic privilege can afford better medical care and to stay home without losing their means of living. One of the less common studies is how people with disabilities are affected by the pandemic. People living with disabilities (PLWD) are affected in mainly three aspects: accessibility to information, accessibility to services, and data collecting. First, PLWD has less access to information about the pandemic because not all relevant information is presented in a format that is accessible to them. Second, due to restrictions of mobility, PLWD can lose access to services they need such as caregivers or therapy. This is especially concerning since many PLWD have comorbidities that can make them even more vulnerable to the virus. Lastly, data collection on the pandemic does not often consider PLWD and thus also affects the inclusive aspect of planning for policies to deal with the pandemic [3]. With their added vulnerability, PLWD should be a case for concern. Mapping techniques have been a crucial tool during the pandemic. Tracking the spread of the virus is essential to prevent the further expansion. Analyzing the pandemic

\footnotetext{
*Corresponding author: ratihfitria.putri@ugm.ac.id
} 
spatially could help identify areas that have higher levels of infection, thus helping to identify which areas are in need of the most help or need to be quarantined. Using GIS, we can also identify what types of people are infected and how they are treated. In this study, mapping will be used to present the patterns of COVID-19 infection and disability in order to achieve better understanding spatially within the region of Sleman District. The COVID-19 infection mapping provides a visualization of the pandemic conditions in Sleman. This is useful in knowing the spatial distribution of COVID-19 infection in this area so that we know which sub-district is most affected by the COVID-19 pandemic. This identification is useful for knowing areas that need attention regarding the COVID-19 pandemic.

Despite various pieces of legislation grouping PLWD as a vulnerable group to consider during disaster management, a previous study conducted in the USA has shown that the correlation between COVID-19 and PLWD is negative [4]. This study which is conducted by dr. Chakraborty uses the same methodology albeit with much more data and slightly different variables. In this paper, we will try to apply the same methodology, but specifically to persons with physical disabilities to see if we would be able to generate the same results.

\section{Data and Method}

\subsection{Data}

Variables used in this study were data on the number of COVID-19 confirmations which were used as the main variable and became the $\mathrm{Y}$ variable, while the $\mathrm{X}$ variable is based on the number of PLWD. The secondary data used in this study are mentioned below.

a. COVID- 19 Confirmation Data per district in Sleman Regency (per 31 December 2020) from government website (Badan Pusat Statistik, Yogyakarta Tanggap COVID-19, and Dashboard COVID-19 Kabupaten Sleman)

b. Physical Disability Data per district in Sleman Regency (for $2^{\text {nd }}$ Semester of 2020) from government website (Governance Bureau of Regional Secretariat of Yogyakarta)

Data collection carried out by collecting secondary data related to the variables to be analyzed through the linked site. This is done to follow health protocols during a pandemic. After that, the data processed using Microsoft Excel, so that the data is obtained in the form of tables and graphs which are then analyzed using descriptive quantitative methods.

\subsection{Pearson Correlation}

Pearson Product-Moment Correlation Coefficient is a method used to find the strength of the relationship between the variables to be studied with a range from -1 to 1 [5]. This method has been used in the United States of America, Spain, Italy, Germany, France, United Kingdom, Belgium, New Zealand, Turkey [6], Poland, Portugal [ 7 ], and India [8]. The two variables investigated in the Pearson Product-Moment Correlation Coefficient method are usually given the symbols the variable $\mathrm{X}$ and variable $\mathrm{Y}$. The correlation is then calculated using formula (1).

$$
r=\frac{n \Sigma x y-(\Sigma x)(\Sigma y)}{\sqrt{\left[n \Sigma x^{2}-(\Sigma x)^{2}\right]\left[n \Sigma y^{2}-(\Sigma y)^{2}\right]}}
$$

where, $(r)$ represents the Pearson Product-Moment Correlation Coefficient, (n) represents the amount of data pairs between $\mathrm{X}$ variable and $\mathrm{Y}$ variable, $(\Sigma \mathrm{x})$ represents the total sum of $X$ variable, $(\Sigma y)$ represents the total sum of $Y$ variable, $\left(\Sigma x^{2}\right)$ represents the square of total sum of $\mathrm{X}$ variable, $\left(\Sigma \mathrm{y}^{2}\right)$ represents the square of total sum of $\mathrm{Y}$ variable, and ( $\Sigma x y)$ represents the product of the total sum of X Variable and Y Variable. The results of the statistical test can fall under one of three categories as follows.

a. Positive correlation

Correlation between variables can be considered positive if an increase in value of variable $\mathrm{X}$ is followed by an increase in value of variable $\mathrm{Y}$, and the decrease in value of variable $\mathrm{X}$ is followed by a decrease of valuein variable $Y$.

b. Negative Correlation

Correlation between variables can be considered negative if an increase in value of variable $\mathrm{X}$ is followed by a decrease in value of variable $Y$, and the decrease in value of variable $\mathrm{X}$ is followed by an increase of valuein variable $Y$.

c. No Correlation

Variables might have no correlation when the decrease and increase in both values happen at random. This indicates that the variables do not affect one another.

Through the aforementioned approach and analysis, it can be declared that this research uses descriptive quantitative research methods. The descriptive research method in conducting analysis covers the COVID-19 phenomenon in Sleman and its correlation with PLWD. The analysis and approach reflect that this research is using quantitative descriptive methods.

\subsection{Spatial Analysis}

Spatial analysis data were collected through online procedure. The administrative boundaries data of subdistricts within the area were downloaded from InaGeoportal, provided by Geospatial Information Agency (Badan Informasi Geospasial). PLWD distribution and 
COVID-19 case maps were composed utilizing QGIS 3.18.3. software. Both PLWD and COVID-19 data were classified into three categories, low, moderate and high using equal interval classification provided by the software. Equal interval classification interprets the input data into three categories with equal amount of range [9].

\subsection{Social Vulnerability}

The indicators used to evaluate social vulnerability during times of disaster are population density and population of vulnerable groups. These indicators are regulated by the National Body of Disaster Management (BNPB) through Peraturan Kepala BNPB Nomor 2 Tahun 2012. According to this regulation, the indicators for vulnerability are: poverty ratio, gender ratio, disability ratio and age group ratio. Here, disability is categorized into physical disability, vision impared, hearing-speech impaired, and mental disability. However. in the case of COVID-19, physical disability is not taken into account since the lack of mobility equals less exposure. Therefore, people who have physical disabilities would not be relevant when evaluating social vulnerability during the COVID-19 pandemic.

\section{Discussion}

\subsection{Pearson Correlation}

Between the variables, PLWD and confirmation cases of COVID-19, the correlation results showed the number of cases is 0.04346 . The correlation result of 0.04346 can show a value that is more than zero, which means that the correlation is positive. However, if it is observed directly through Figure 1. that the scatterplots are far away from the line so that the correlation number is approximately zero as shown in Table 1 . Because, a value of zero indicates no relationship between the two variables being compared. Thus, the change in one variable is not directly proportional or inversely proportional to the other variable and correlation is classified as very low positive.

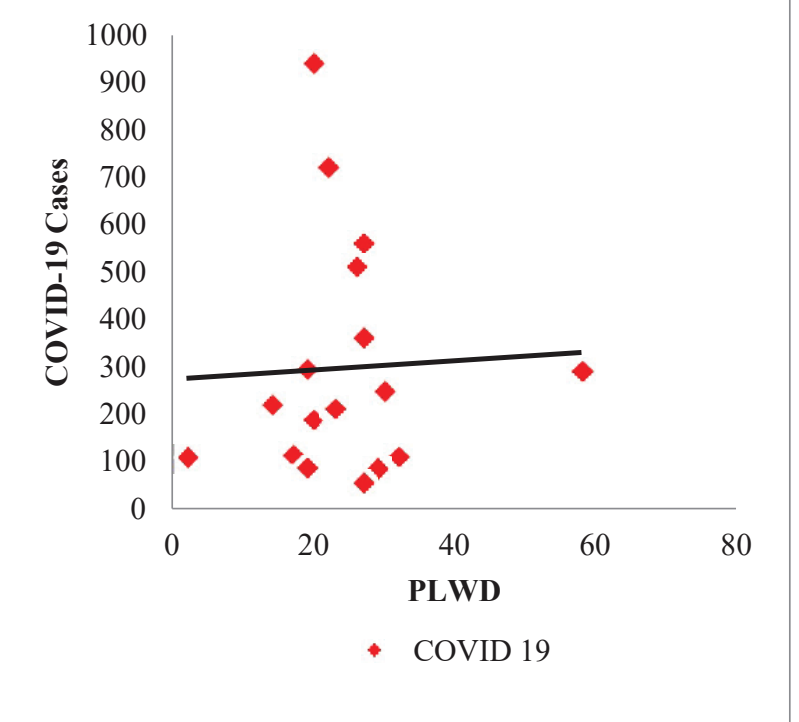

Fig. 1. Pearson Correlation Chart between Variable PLWD and Confirmed Cases of COVID-19
The observation results from Figure 1 which shows an image of the irregular correlation can also be observed from the inconsistency of the correlation, where there is a correlation with a high number of confirmed COVID-19, but the number of PLWD in the area is not many. On the other hand, there is also a low number of confirmed cases of COVID-19, but there are a lot of PLWD. Thus, value of the graph shows an inconsistent up and down correlation. The correlation results for each District in Sleman Regency presented in Table 1. The highest confirmed numbers of COVID- 19 are in several districts, including Depok District with 938 people, Ngaglik District with 718 people, Gamping District with 557 people, and Mlati District with 507 people. Meanwhile, the lowest number of COVID-19 was in Cangkringan District with 51 people, Pakem District with 80 people, and Turi District with 82 people. The highest number of disabilities was in Ngemplak District with 58 people, Moyudan District with 32 people, and Tempel District with 30 people. Meanwhile, the lowest number of people with disabilities is in Minggir District with 2 people, Sleman District with 14 people, and Prambanan District with 17 people. From the data in areas with high numbers of confirmed COVID19 , it shown relatively low or moderate disability rate. The highest number of disabilities in each sub-district did not show a high number of confirmed positive COVID-19 aswell.

Table 1. Table of Data and Calculation Results for each District in Sleman Regency

\begin{tabular}{|c|c|c|c|c|}
\hline No. & District & $\begin{array}{l}\text { PLWD } \\
\text { Physical }\end{array}$ & $\begin{array}{c}\text { Covid-19 } \\
\text { Cases }\end{array}$ & \begin{tabular}{c|} 
Pearson \\
Correlation
\end{tabular} \\
\hline 1 & Moyudan & 32 & 106 & \multirow{17}{*}{0.043461309} \\
\hline 2 & Minggir & 2 & 105 & \\
\hline 3 & Seyegan & 20 & 185 & \\
\hline 4 & Godean & 19 & 291 & \\
\hline 5 & Gamping & 27 & 557 & \\
\hline 6 & Mlati & 26 & 507 & \\
\hline 7 & Depok & 20 & 938 & \\
\hline 8 & Berbah & 23 & 208 & \\
\hline 9 & Prambanan & 17 & 109 & \\
\hline 10 & Kalasan & 27 & 357 & \\
\hline 11 & Ngemplak & 58 & 287 & \\
\hline 12 & Ngaglik & 22 & 718 & \\
\hline 13 & Sleman & 14 & 217 & \\
\hline 14 & Tempel & 30 & 245 & \\
\hline 15 & Turi & 19 & 82 & \\
\hline 16 & Pakem & 29 & 80 & \\
\hline 17 & $\begin{array}{l}\text { Cangkring } \\
\text { an }\end{array}$ & 27 & 51 & \\
\hline
\end{tabular}

\subsection{Spatial Distribution}

The distribution of PLWD in Sleman District represented Figure 2. Population of PLWD is higher on the east and southwest side of Sleman, with the 
highest disabled populations located in the Ngemplak sub-district. Areas with a high population of PLWD are not likely to be the center of regional activities. and located near the border with neighboring districts that are not the center of regional activities. Being far from the center of regional activities, the location is expected to be less crowded and more peaceful, so that PLWD do not experience disturbance from the surroundings.

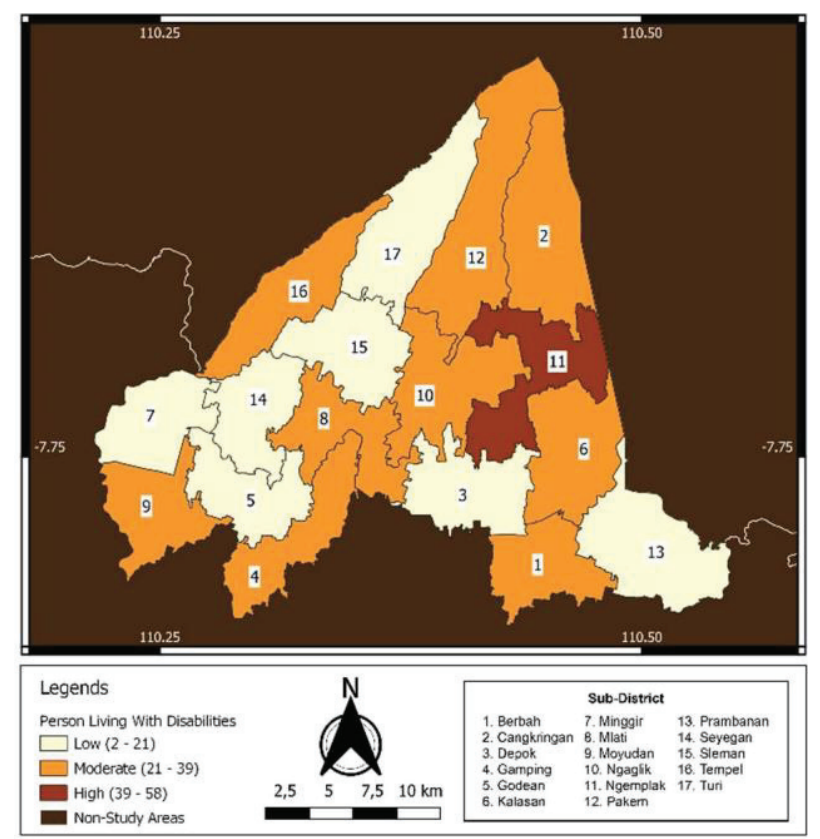

Fig. 2. Spatial Distribution of PLWD in Sleman

Distribution of COVID-19 cases in Sleman is influenced by the activities of the people. As shown in Figure 3., Depok sub-district record the highest COVID19 cases. The mentioned sub-district is the center of public activities in Sleman with various commercial districts and public spaces. Although we saw restriction of public spaces activities such as reducing the operating hours of public spaces and stores, Sleman doesn't implement strict lockdown regulation to keep local business running. Thus, there is still a possibility of COVID-19 disease could easily spread within the population in the area with high public physical contact. Sub-districts with low COVID-19 cases were mostly rural areas with less physical activity compared to sub-districts with high COVID-19 cases. Activities in the rural subdistricts most dominantly occurred within the population of the respective areas, while activities in the Depok subdistrict involves people from the outside of the area as well.

COVID-19 cases in Sleman Regency that are more concentrated on Ngaglik and Depok Sub-districts indicate that COVID-19 cases are easier to spread in public activity centers, which are commercial and densely populated areas. This phenomenon supports the research conducted by Duran-Polanco and Siller [10] which states that public areas are prone to the spread of COVID-19 because there are possibilities of people interacting physically. PLWD tend to live in areas that are not the centers of public activity, such as in Ngemplak Subdistrict, which has the highest distribution of PLWD. This is a positive phenomenon because people with disabilities have a lower probability of contracting the COVID-19 virus that is spreading in the community. Nevertheless, attention to cases of COVID-19 for PLWD is still needed, especially in Ngaglik Sub-district but with persons with moderate disabilities, having high COVID-19 cases.

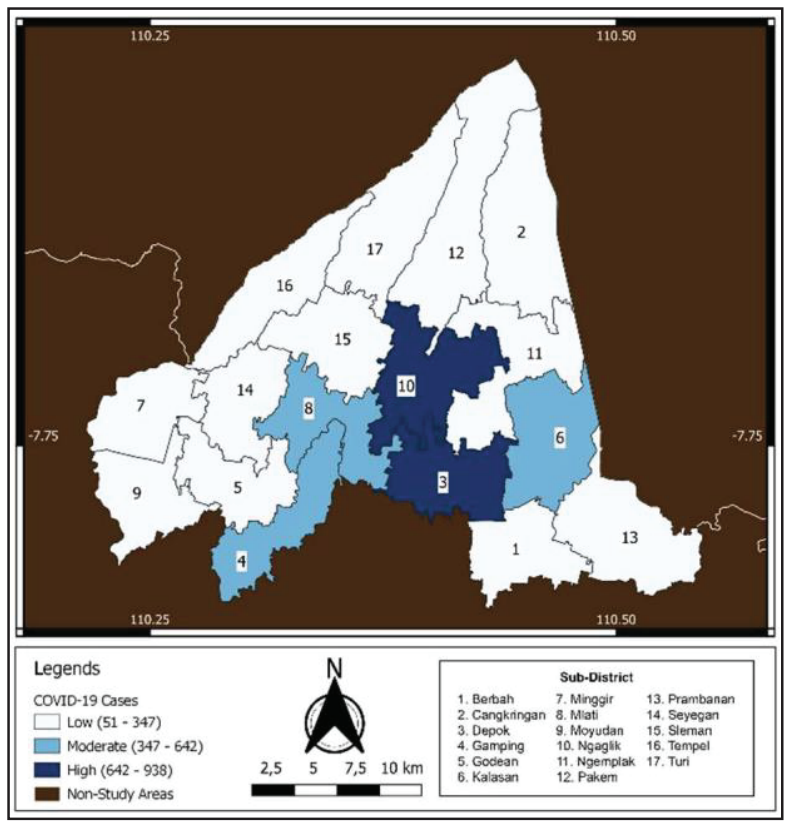

Fig. 3. Spatial Distribution of COVID-19 Cases in Sleman

\subsection{Social Vulnerability}

The Pearson calculations show that the data does have a positive correlation. The number is too small to be regarded as significant, however we should recognize a few limitations in our study. First, the data analyzed is comparing PLWD populations with the number of infected by COVID-19 people overall, not the number of PLWD infected. If we were to use the latter such as similar studies before us, the correlation might be much stronger. On the contrary, a similar study from the US showed a negative correlation despite using the proper data [4]. Second, this study only analyses physical data disability, instead of disability as a whole. One of the effects of the pandemic is a restriction of mobility, which is an already familiar experience to people with physical disabilities. In fact, this restriction could be an advantage for them since now most services and facilities operate remotely, in comparison to life before the pandemic when not all services would operate this way. Not all persons with physical disabilities suffer from similar afflictions and some might require regular physical therapy or assistance which is often inaccessible in our work from home society.

In accordance to the previous study [4], there has been a decrease in neurorehabilitation rates for stroke, as much as $50 \%$ in Italy. When services reopened, the rates of neurorehabilitation saw an increase, due to complications of COVID-19 and postponed medical appointments for those already with reduced mobility due to neurological inflictions. This could lead to a further slowing down 
of medical services that are already congested due to the pandemic. The publication also concluded that remote services for this kind of treatment aren't effective - in person appointments are still necessary [11]. Although people suffering physical disabilities may have less exposure to the virus, they still feel the side-effects the pandemic has brought upon them.

The challenges faced by PLWD as a vulnerable group, especially during the pandemic, should be given serious attention. Even in normal circumstances, PLWD have higher rates of depression than most of the population [12]. People with physical disabilities have specific needs, therefore depend on medical services and caregivers [13]. The social restrictions and compulsory mask-wearing that have been set by the government limits the interactions between PLWD and their caregivers. The combination of these conditions made PLWD a vulnerable group during the COVID-19 pandemic [14].

\section{Conclusion}

This study shows that the correlation between PLWD and COVID-19 has no correlation. This phenomenon is caused by the results which show the number of cases is 0.04346 . A value of zero indicates that there is no relationship between the two variables being compared. So, that it can be said that the correlation shows or can be classified as very low positive or uncorrelated. The graph shows an irregular correlation of the inconsistency and the correlation, where there is a correlation with a high number of confirmed COVID-19, but the number of PWLD in the area is not large. On the other hand, there are also few confirmed cases of COVID-19, but many PLWD. The graph value shows an inconsistent up and down correlation. PLWD, especially people with physical disabilities, have lower risk to COVID-19 due to lack of mobility and lower exposure. Thus, including people with physical disabilities as one of indicators of social vulnerability is insignificant. In the case of COVID-19, people with chronic illness are the vulnerable group which need more attention in order to be able to reach medical treatment that is often constrained by limited access.

The spatial distribution of PLWD was concentrated on the east side of Sleman, not likely to be the center of public activities. The location is expected to be less crowded and more peaceful, so that PLWD do not experience disturbance from the surroundings. Distribution of COVID-19 in Sleman was centralized in Depok Sub- district, which served as the center of public activities. The low COVID-19 cases were recorded in rural areas because it has lower physical contact activities within the area compared to Depok Sub-district.

\section{Acknowledgment}

This study is a part of Program Riset Besar (Grand Research Program) conducted by Geography Study Club, Faculty of Geography, Universitas Gadjah Mada. We would like to thank the institution that provided us with the online data used in this study, as well as the
Faculty of Geography, Universitas Gadjah Mada for their support.

\section{References}

1. R. K. Mohapatra, L. Pintilie, V. Kandi, A. K. Sarangi, D. Das, R. Sahu, and L. Perekhoda, Chem. Biol. Drug Des. 96, 1187 (2020)

2. H. Coşkun, N. Yıldırım, and S. Gündüz, Sci.Total Environ. 751, (2021)

3. H. Kuper, L. M. Banks, T. Bright, C. Davey, and T. Shakespeare, Wellcome Open Res. 5, 1 (2020)

4. J. Chakraborty, Disabil. Health J. 14, 101007 (2021)

5. N. Al-Rousan and H. Al-Najjar, Eur. Rev. Med. Pharmacol. Sci. 24, 4565 (2020)

6. D. Gondauri and M. Batiashvili, Electron. J.Gen. Med. 17, 17 (2020)

7. A. Strzelecki, A. Azevedo, and A. Albuquerque, Healthc. 8, (2020)

8. A. K. Upadhyay and S. Shukla, Diabetes Metab. Syndr. Clin. Res. Rev. 15, 993 (2021)

9. Paul Bolstad, GIS Fundamentals : A First Text on Geographic Information System5 Th Edition (2016)

10. L. Durán-Polanco and M. Siller, Annu. Rev. Control (2021)

11. L. Leocani, K. Diserens, M. Moccia, and C. Caltagirone, Eur. J. Neurol. 27, e50 (2020)

12. M. V. S. Gudlavalleti, N. John, K. Allagh, J. Sagar, S. Kamalakannan, S. S. Ramachandra, B. R. Shamanna, C. Noe, H. B. Pant, F. Soji, and S.Mani, BMC Public Health 14, 1 (2014)

13. N. Scherer, I. MacTaggart, C. Huggett, P. Pheng, M. U. Rahman, and J. Wilbur, BMJ Open 11, 1(2021)

14. A. Lebrasseur, N. Fortin-Bédard, J. Lettre, E. L. Bussières, K. Best, N. Boucher, M. Hotton, S. Beaulieu-Bonneau, C. Mercier, M. E. Lamontagne, and F. Routhier, Disabil. Health J. 14, (2021) 